Open Access

\title{
Determinants of household food insecurity in Mexico
}

\author{
David Magaña-Lemus ${ }^{1 *}$, Ariun Ishdorj ${ }^{2}$, C. Parr Rosson $\left.1\right|^{2}$ and Jorge Lara-Álvarez ${ }^{1}$
}

\author{
* Correspondence: \\ dmagana@fira.gob.mx \\ ${ }^{1}$ Economic Researcher, Fira, México \\ Full list of author information is \\ available at the end of the article
}

\begin{abstract}
Using a national household survey and a newly established food security scale, socio-demographic factors affecting the level of household food insecurity in Mexico were identified. Households more likely to be food insecure include those with younger, less-educated household heads, headed by single, widowed or divorced women, with disabled household members, with native language speakers, with children, as well as rural and lower-income households. The model was also estimated for the rural and lower-income subpopulation, finding that low levels of education, native language speakers, and number of kids are factors associated with higher levels of food insecurity.
\end{abstract}

Keywords: Food security scale, Household food insecurity, Mexico

JEL classification: D10, D60, 110, I30

\section{Background}

The importance of food security has been addressed nationally and internationally. Food security is defined as the situation when all people, at all times, have physical and economic access to sufficient, safe, and nutritious food to meet their dietary needs and food preferences for a healthy and active life (FAO 1996). At a global level, the number of people suffering from hunger and poverty exceeds one billion, which represents one-seventh of the world's population (FAO 2009). As for the situation in Mexico, in 2010 the proportion of population that suffered from any level of food insecurity was $44.3 \%$. In particular, $19.5 \%$ of the Mexican population reported experiencing very low food insecurity, $14.0 \%$ moderate food insecurity, and $10.8 \%$ severe food insecurity. In terms of the number of persons, 49.9 million people in Mexico were experiencing some degree of food insecurity in 2010 (Consejo Nacional de Evaluación de la Política de Desarrollo Social CONEVAL 2011a). In 2008, the proportion of Mexican population under moderate food insecurity and severe food insecurity was $12.8 \%$ and $8.9 \%$, respectively. This means that the two most severe levels of food insecurity in Mexico increased from 2008 to 2010 (Consejo Nacional de Evaluación de la Política de Desarrollo Social CONEVAL 2011a).

Food security is an essential dimension of household welfare and an important subject whether viewed globally, within a nation, a state, or in local communities (Bickel et al. 2000). Negative consequences of food insecurity have been documented extensively. Ramsey et al. (2011) found that children in food-insecure households may be at

(C) 2016 Magaña-Lemus et al. Open Access This article is distributed under the terms of the Creative Commons Attribution 4.0 International License (http://creativecommons.org/licenses/by/4.0/), which permits unrestricted use, distribution, and reproduction in any medium, provided you give appropriate credit to the original author(s) and the source, provide a link to the Creative Commons license, and indicate if changes were made. 
risk of poor health, developmental or behavioral problems. Likewise, Jyoti et al. (2005) provide strong empirical evidence that food insecurity is linked to nutritional and nonnutritional developmental consequences for children, in particular, academic performance and social skills are found to be affected by food insecurity. Cook et al. (2006) found that household food insecurity is positively associated with fair/poor health and hospitalizations in young children. Moreover, Carmichael et al. (2007) suggest that increased risks of certain birth defects may be included among the negative consequences of food insecurity.

Food insecurity is one of the most important public health challenges. To fight food insecurity and its associated consequences requires an understanding of the determinants of food insecurity (Gundersen and Garasky 2012). Despite the fact that food insecurity and hunger are consequences of constrained financial resources, the usual income and poverty measurements do not provide clear information about food security. Evidence supported by analysis of food security data indicates that many low-income households seem to be food secure, while a small proportion of non-poor households appear to be food insecure (Bickel et al. 2000). Likely reasons for such findings include variations in household decisions about how to handle competing demands for limited resources, as well as geographic patterns of relative costs and availability of food and other basic necessities. In other words, the food security measure provides independent, more specific information on this dimension of welfare than the measure that can be inferred from using only income data (Bickel et al. 2000). If food insecurity was completely determined by other measures of constrained resources, poverty for example, establishing a measurement of food insecurity would be irrelevant. However, research has shown that income-based measures and other measures of well-being are not necessarily highly correlated with food insecurity and hunger (Gundersen 2008).

As pointed out by Bickel et al. (2000), monitoring food security can be useful to identify and understand this basic welfare aspect and to recognize population subgroups or regions with particularly severe conditions. Therefore, determining the food security status of the households comprising the community can provide a tool for assessment and planning of governmental programs and policies aimed to enhance food security and reduce hunger.

The main objective of this research is to identify social-demographic factors that determine the level of food insecurity in Mexico. In other words, vulnerable groups in terms of food security are to be identified. The initial hypothesis of this research is that rural households with less educated and native head of household will be more prone to be food insecure. The classification of food security households is achieved through the use of the newly established Mexican Food Security Scale (EMSA, Spanish acronym) and a nationally representative dataset containing detailed household -and individual-level information.

Until the authors knowledge, despite the demonstrated validity of the food security scale, there is no available study that has utilized food security scales to identify the sociodemographic factors that determine household food (in) security at a national level in Mexico. This study precisely address that gap in the existing literature. It is important to notice that a clear understanding of the factors that determine (or are correlated with) food insecurity can improve the design of future agricultural and development policies aimed to promote household food security and child nutrition in Mexico. 


\section{Literature review}

During the last decade a renewed interest in the concept of food insecurity at the household level has emerged (González et al. 2008). As recent experience suggests, household food insecurity and its severity can be measured through simple and short questionnaires, allowing to collect valuable information with low cost and low respondent burden (González et al. 2008).

The literature has established socioeconomic and demographic factors associated with food insecurity in the United States. Among the groups of people that are found more likely to be food insecure are: households headed by an African American person, Hispanic households, a non-married person, a divorced or separated person, a renter, younger persons, and less educated persons. Moreover, households with children are more likely to be food insecure than households without children. In previous studies, the aforementioned characteristics are generally positively associated with food insecurity (Gundersen, Kreider, and Pepper 2011). However, these authors also recognize that an important factor is the amount of money available to a household, which in some cases is included in estimation methods as income normalized by the poverty line. Similarly, Hager et al. (2010) reports that in the United States, black or Hispanic households with single parents, young children, and incomes below the federal poverty line were identified to have increased risk for food insecurity in 2008.

Evidence support that household questionnaires to collect food security information has been successfully applied in the United States, and they can be applicable in other countries, with appropriate linguistic and cultural conversions, reflecting the characteristic patterns of perception and response within the sampled population (Bickel et al. 2000). As for the performance of this type of measures of food insecurity in developing countries, Melgar-Quiñonez et al. (2006) examined the association between food insecurity, determined by a modified version of the U.S. Household Food Security Survey Module, and total daily per capita consumption - measured as household expenditures - in Bolivia, Burkina Faso, and the Philippines. Daily per capita food expenditure, which represented over $60 \%$ of the total household consumption, as well as expenditures on specific food groups correlated with food insecurity both as a continuous Food Insecurity Score and as a tri-categorical food insecurity status variable. The authors found that food secure households have significantly higher total daily per capita food expenditures as well as expenditures on animal source foods, vegetables, and fats and oils than moderately and severely food-insecure households. Another example of household food security questionnaire is González et al. (2008). The authors developed a 14-item questionnaire to measure household food insecurity in urban Costa Rica. Likewise, Pérez-Escamilla et al. (2004) validated a food security scale in Brazil. They also reported that food security is strongly associated with the likelihood of daily consumption of fruit, non-root/tuber vegetables, and meat. In other words, the authors found a negative association between food insecurity and the probability of daily consumption of fruits, vegetables and animal protein. Other studies that have successfully validated the household food security scale, as a measure to identify the actual magnitude and severity of food security, in a development setting include: Álvarez et al. (2006) that conducted a study in Antioquia, Colombia; as well as Gulliford, Mahabir, and Rocke (2004) that studied food security in a Caribbean community, among others. 
In 2008, the Latin American and Caribbean Food Security Scale (ELCSA) was part of the opinion survey "Barómetro de las Américas". This survey was applied to a sample of 1511 households in Mexico. It was representative at a national scale and for four geographic regions. It was found a $52 \%$ of food insecure level (30 \% Very Low Food Insecurity, 13 \% Moderate Food Insecurity, 9 \% Severe Food Insecurity) (FAO, 2012).

All these experiences offer evidence that the U.S. Household Food Security Survey Module is able to discriminate between households at different levels of food insecurity status in diverse developing world settings. Also, these studies show that the adapted questionnaire is a valid measurement of household food insecurity. Further, they observe that this is a simple and quick method to apply in a household setting.

Related to a validation of the scale in Mexico, Melgar-Quiñonez et al. (2005) conducted a study to validate a version of the Food Security Survey (FSS), used by the U.S. Department of Agriculture, in communities located in Sierra de Manantlán, Jalisco western Mexico-. The FSS was modified to fit the Mexican context. Namely, the questionnaire was translated to Spanish and the questions were reworded in a way that they were unambiguously understood by locals. Moreover, the authors recorded a 24-h diet recall as nutritional assessment in every interviewed household; this metric was compared to the food security survey outcome. The modified FSS was validated in correlation with a household food inventory and the household dietary variety. They found that food insecurity was associated with low dietary variety. In particular, food insecurity was inversely correlated with the number of food items in the household, animal source foods, dairy products, fruits, and vegetables. The authors concluded that the FSS is a useful tool for monitoring food insecurity in rural regions of Jalisco, Mexico. Moreover, Pérez-Escamilla, Paras, and Hromi-Fiedler (2008) tested the validity of the ELCSA in a representative public opinion survey in the state of Guanajuato, Mexico. ELCSA contained 16 items and used a reference period of 3 months. In both experiences with ELCSA, the authors conclude that using a food security scale, such as ELCSA is a valid tool for assessing household food insecurity in Mexico.

One of the few studies on the subject that used food expenditures data and food security in Mexico is Carrasco et al. (2010). Following the hypothesis that households with higher degree of food insecurity are expected to have less varied diets than food secure households they conducted a correspondence analysis, finding a slight association between food security and a more varied diet, measured through food expenditure in households.

\section{Methods}

The problem of food security is multifactorial. Within a household, food insecurity should be understood as a problem of 1) food availability, 2) food access, and 3) food consumption (Consejo Nacional de Evaluación de la Política de Desarrollo Social CONEVAL 2010). In macro terms, as for food availability, between 2003 and 2005 there was adequate food availability in Mexico. That is, the minimum requirements for the Mexican population was of 1850 kilocalories per capita per day, while the food supply reached 3270 kilocalories per capita per day (Consejo Nacional de Evaluación de la Política de Desarrollo Social CONEVAL 2010). Nevertheless, in terms of food access $18.2 \%$ of the Mexican population had income below the food poverty line in 2008, which means that they did not have enough income to buy a representative basic food basket (Consejo Nacional de 
Evaluación de la Política de Desarrollo Social CONEVAL 2010). Finally, in terms of food consumption, in 2008 only a small proportion of rural households had a diversified diet, according to health recommendations (Consejo Nacional de Evaluación de la Política de Desarrollo Social CONEVAL 2010). This is the macro panorama, however, the macro variable for national food availability is not always informative of food availability for each household. The same can be said of the macro variable for food access and food consumption (Magaña-Lemus and J. Lara-Álvarez 2015). For that reason, in this research data at the household level will be used.

\section{Mexican food security scale}

The data used in this study come from the Module of Socioeconomic Conditions from 2010 (Instituto Nacional de Estadística y Geografía. México INEGI (2011) of the National Household Income and Expenditure Survey (ENIGH, Spanish acronym) collected from August 21st to November 28, 2010. It is worth noting that since 2008, the survey has undergone a series of changes. Among these is the inclusion of Mexican Food Security Scale (EMSA, Spanish acronym), an instrument which addresses the dimension of access to food, which is useful for the new poverty estimates in the country. The scale is constructed from a battery of twelve questions that consider the quality and adequacy of food through the reporting of experiences of the population. The EMSA measures the degree of household food insecurity and is the instrument to measure the lack of access to food. This newly implemented scale is used in this research.

EMSA was derived from the Latin American and Caribbean Food Security Scale (ELCSA) (Villagómez-Ornelas et al. 2014), ${ }^{1}$ which in turn, takes as a main reference the U.S. Household Food Security Survey Module. This is not new, as countries like Canada and Brazil have adapted this questionnaire to the context of their countries. The U.S. Household Food Security Survey Module, unlike the Mexican EMSA, included questions about fear feelings regarding not having money to buy more food before it finishes. One can guess that a similar question, in Mexico, might receive many positive answers that would be correlated with lack of development of the labor market. On the other hand, it can be expected that households in a developed country, such as United States, will enjoy a better financial stability; therefore, a fear of not being able to buy enough food is a good indicator of food insecurity. On the other hand, the EMSA asks directly whether the household had enough money to buy food. Another difference is that the U.S. Household Food Security Survey Module asks whether food insecurity might deteriorate household members' health. In the EMSA, there is not such a question. Finally, the American questionnaire includes a question about buying low-priced food for children; in the Mexican survey, there is not such a question, probably because those products are not as popular in Mexico. The rest of the questions are very similar.

The set of food security questions included in the MSC 2010 survey can be combined following the official methodology of Consejo Nacional de Evaluación de la Política de Desarrollo Social (CONEVAL) (2011b) - into a single overall measure called the Mexican Food Security Scale (EMSA). ${ }^{2}$ This is a scale that measures, using a single numerical value, the level of food insecurity experienced by a household. That is, the dependent variable in the model can have four different levels of food security that are defined following the 
criteria specified in the EMSA. CONEVAL validated EMSA as a reliable instrument to measure food security at the national and state level in Mexico (Carrasco et al. 2010).

\section{Data description}

The data set used is nationally representative and provides detailed household and individual-level information. The MCS 2010 offers nationwide results, for urban and rural population in every State. The total sample consists of more than 60,000 households. The ENIGH is the only official nationally representative data in Mexico that contains data on food security and food expenditures at the household level. The MCS 2010 is a joint effort between two Mexican Institutions: the National Institute of Statistics and Geography (INEGI) and the National Council for Evaluation of Social Development Policy (CONEVAL). The objective of this joint effort was to provide a statistical overview of variables needed for the multidimensional measurement of poverty, which was stipulated by the Law on Social Development.

Technically, the distinction between the levels of food insecurity is constructed after distinguishing between households with adults only and those with children under 18. In the first case, the scale uses values between zero and six, whereas in the second case, it uses values between zero and twelve. This is because for households with children six additional questions about the experience of food shortage or hunger are asked. Once this distinction is performed, the scale identifies four breakpoints: 1) food security (no affirmative answers to any of the food insecurity/hunger questions); 2) very low food insecurity (one or two positive answers in households without children, and one to three affirmative answers in households with children); 3) moderate food insecurity (three to four positive answers in households without children, and four to seven in homes with minors); and 4) severe food insecurity (five or six affirmative responses for households without children, and eight to twelve positive answers in the case of households with children).

All of the food security questions in the EMSA have two common characteristics. Each question includes a phrase such as "due to lack of money or resources" to assure that the reported hunger experience or food unavailability condition occurred because of household financial/resource limitations. It is important to notice that the term "resources" imply the possibility of obtaining or producing the food for the household without the need to use money. This opens up the possibility of obtaining food from own production and/or subsistence farming, something very common especially in rural communities across Mexico. Moreover, each question asks explicitly about circumstances that occurred during the past 3 months.

\section{Economic model}

The four categories in the EMSA are: 1 = Food Security, 2 = Very Low Food Insecurity, 3 = Moderate Food Insecurity, 4 = Severe Food Insecurity. Food Security status will be denoted by $y$, then for each household $i$, its food security status can be catalogued as $y_{i}=1,2,3,4$. The question that would be explored is, how food security is affected by sociodemographic characteristic? Therefore, the object of interest is

$$
\operatorname{Pr}\left(y_{i}=1,2,3,4 \mid x_{i}\right)
$$

That is, a model to estimate the probability of food security status conditional upon socio-demographic characteristics $\left(x_{i}\right)$ is needed. 
Food security status is a constrained choice. Households choose their status given their income, member's composition, education, and context variables (local markets situation, for instance). The notation would be the following: the $i$ th household's utility for each food security status is denoted by $u_{i}^{y_{i}}\left(x_{i}\right)$. Then assuming each utility function is additive in socioeconomic characteristics:

$$
u_{i}^{y_{i}}\left(x_{i}\right)=x_{i} \alpha+\mu_{i}
$$

This is the so-called Random Additive Utility Model. In addition, valued functions can be defined, with the investment cost $I$ that represents the necessary investment (effort) to belong to each food security status. Then, the investment, require decreases as food insecurity increases.

$$
\begin{aligned}
& V\left(1, x_{i}, \mu_{i}\right)=1\left\{\left(x_{i} \alpha+\mu_{i}\right)-(I-1 \gamma)\right\} \\
& V\left(2, x_{i}, \mu_{i}\right)=2\left\{\left(x_{i} \alpha+\mu_{i}\right)-(I-2 \gamma)\right\} \\
& \left(x_{i} \alpha+\mu_{i}\right)-(I-1 \gamma)>2\left\{\left(x_{i} \alpha+\mu_{i}\right)-(I-2 \gamma)\right\} \\
& -I+1 \gamma+2 I-4 \gamma>x_{i} \alpha+\mu_{i} \\
& I-3 \gamma>x_{i} \alpha+\mu_{i} \\
& I-3 \gamma=\tau_{1}
\end{aligned}
$$

And, accordingly, for the other categories we can define $\tau_{2}$, and $\tau_{3}$.

$$
y=\left\{\begin{array}{c}
1 \text { if } x_{i} \alpha+\mu_{i}<\tau_{1} \\
2 \text { if } \tau_{1}<x_{i} \alpha+\mu_{i}<\tau_{2} \\
3 \text { if } \tau_{2}<x_{i} \alpha+\mu_{i}<\tau_{3} \\
4 \text { if } \tau_{3}<x_{i} \alpha+\mu_{i}
\end{array}\right.
$$

That is, a household would prefer to stay food secure if the "investment difference" $\left(\tau_{1}\right)$ is not too big, or would allocate in the other categories according to their maximization outcome. The empirical implication of this model is that it tests whether the socioeconomic characteristics and context variables affects food security status through "index shift" $\tau$.

Therefore, assuming $\varepsilon_{i}$ is $i i \mathrm{~d}$ and $\varepsilon_{i} \mid x_{i} \sim \mathrm{N}(0,1)$, we can estimate an ordered probit of the form. ${ }^{3}$

$$
y_{i}=x_{i} \alpha+\mu_{i}
$$

Then, the log-likelihood for the individual is:

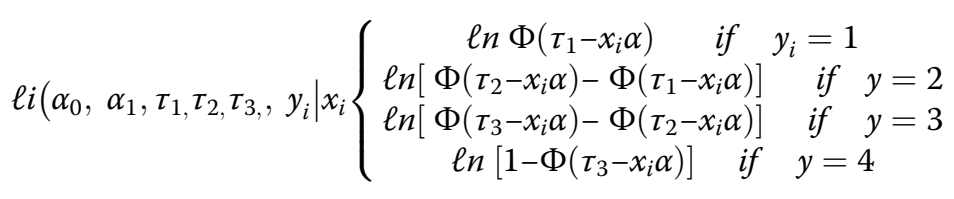

The optimization of the likelihood function will provide the cutoff point's estimates $\left(\widehat{\tau_{1}}, \widehat{\tau_{2}}, \widehat{\tau_{3}}\right)$ and the vector $\hat{\alpha}$ of parameters. Marginal effects in the ordered probit are analogous to marginal effects in the probit model. A marginal effect is defined as the partial derivative of $y$ with respect to $x_{k}$. For nonlinear models, such as ordered probit, the value of the marginal effect depends on the particular values of all the covariates (Long and Freese 2006). 
As for the explanatory variables, the vector of covariates, $x_{i}$, is divided into three types of social-demographic characteristics: 1) household head characteristics, 2) households characteristics, and 3) community and regional variables. Regional refers to a group of states according to socioeconomic indicators (Instituto Nacional de Estadística y Geografía. México INEGI 2012). Definition and descriptive statistics of explanatory variables are presented in Table 1.

The objective of this research is to analyze which socio-demographic factors affects the decision of food security status for each household. For that purpose, we estimate the marginal effects for each category. Those marginal effects are shown in Table 2. The standard errors were obtained using a robust covariance matrix estimation. (Greene 2012). ${ }^{4}$

\section{Results and discussion}

The final sample size after accounting for relevant demographic variables and the variables needed to calculate the household food security is 61,467 households. Every observation (household) in this nationally representative sample is weighted according to the complex sampling design (INEGI, 2011). Sampling weights are provided in the dataset and used to obtain summary statistics and estimates.

Table 1 shows the weighted summary statistics of demographic variables for the whole sample, as well as for the four different levels of food security status. From the 2010 sample, $59.4 \%$ of the households are food secure, $18.5 \%$ have very low food insecurity, $12.1 \%$ of the Mexican households have moderate food insecurity, whereas $10.1 \%$ report severe food insecurity. The proportions of food security status presented here slightly differ from proportions presented in the introductory section of this document. The reason is that in the introduction the proportion term refers to total population (sum of individuals), while in this section it refers to proportion of total number of households.

The poverty lines mentioned in Table 1 are as officially defined by CONEVAL, Mexican Institution in charge of this task. Poverty lines are measured in monthly per capita income, adjusted monthly by the consumer price index, and classified for rural and urban households. The food poverty line is a monetary measure of the resources needed to buy a representative food basket in Mexico. For the last quarter of 2010, the food poverty line was MX\$797.29 for a rural household, and MX\$1,074.28 for an urban household. Likewise, the assets poverty line is defined as the income needed to afford food, education, health, clothing, housing and transportation. The assets poverty line was $M X \$ 1,446.76$ for a rural household, and MX\$2,155.43 for an urban household during the last quarter of 2010.

In terms of household income levels, $16 \%$ of the total households in the sample have income below the food poverty line (lower income), $27 \%$ have income above the food poverty line but below the assets poverty line (low income), $31 \%$ of households are classified as middle income, and the remaining $26 \%$ of households have higher income. Interestingly, $9 \%$ of the households that are food secure are households with incomes below the food poverty line (lower income), whereas $22 \%$ of the households that are food secure with income below the asset poverty line. This finding is in line with (Bickel et al. 2000), who argued that it is likely to find food insecure households in both sides of the poverty line, this was mainly due to variations in household decisions about how to handle competing demands for limited resources, as well as geographic patterns of relative costs and availability of food and other basic necessities. Therefore, it is clear 
Table 1 Variable names, definitions, and descriptive statistics related to food security levels

\begin{tabular}{|c|c|c|c|c|c|c|}
\hline \multirow[b]{2}{*}{ Variable } & \multirow[b]{2}{*}{ Definition } & \multirow[b]{2}{*}{ All obs. } & \multirow[b]{2}{*}{ Food security } & \multicolumn{3}{|c|}{ Food insecurity } \\
\hline & & & & Very low & Moderate & Severe \\
\hline Proportion of Households & & $100 \%$ & $59 \%$ & $18 \%$ & $12 \%$ & $10 \%$ \\
\hline \multicolumn{7}{|l|}{ Household Head Characteristics } \\
\hline Age $<=30$ & Dummy variable, 1 if household head's age is $<=30,0$ otherwise. & $14 \%$ & $13 \%$ & $15 \%$ & $15 \%$ & $14 \%$ \\
\hline Age $31-45$ & Dummy variable, 1 if household head's is age $>=31$ and $<=45,0$ otherwise. & $35 \%$ & $35 \%$ & $34 \%$ & $41 \%$ & $35 \%$ \\
\hline Age $46-60$ & Dummy variable, 1 if household head's is age $>=46$ and $<=60,0$ otherwise. & $29 \%$ & $30 \%$ & $28 \%$ & $27 \%$ & $29 \%$ \\
\hline Age $>=61$ & Dummy variable, 1 if household head's is age $>=61,0$ otherwise. & $21 \%$ & $22 \%$ & $22 \%$ & $17 \%$ & $21 \%$ \\
\hline TOTAL & & $100 \%$ & $100 \%$ & $100 \%$ & $100 \%$ & $100 \%$ \\
\hline Male & Dummy variable, 1 if household head's gender is male, 0 otherwise. & $76 \%$ & $77 \%$ & $78 \%$ & $76 \%$ & $71 \%$ \\
\hline \multirow[t]{2}{*}{ Female } & Dummy variable, 1 if household head's gender is female, 0 otherwise. & $24 \%$ & $23 \%$ & $22 \%$ & $24 \%$ & $29 \%$ \\
\hline & & $100 \%$ & $100 \%$ & $100 \%$ & $100 \%$ & $100 \%$ \\
\hline No Formal education & Dummy variable, 1 if household head has no formal education, 0 otherwise. & $9 \%$ & $6 \%$ & $11 \%$ & $12 \%$ & $18 \%$ \\
\hline Elementary & $\begin{array}{l}\text { Dummy variable, } 1 \text { if household head has elementary school as maximum level of formal } \\
\text { education, } 0 \text { otherwise. }\end{array}$ & $37 \%$ & $32 \%$ & $44 \%$ & $47 \%$ & $47 \%$ \\
\hline Secondary & $\begin{array}{l}\text { Dummy variable, } 1 \text { if household head has high school as maximum level of formal education, } \\
0 \text { otherwise. }\end{array}$ & $27 \%$ & $27 \%$ & $29 \%$ & $28 \%$ & $26 \%$ \\
\hline High School & $\begin{array}{l}\text { Dummy variable, } 1 \text { if household head has junior high school as maximum level of formal } \\
\text { education, } 0 \text { otherwise. }\end{array}$ & $12 \%$ & $15 \%$ & $10 \%$ & $8 \%$ & $7 \%$ \\
\hline College & Dummy variable, 1 if household head has college or graduate school as formal education, 0 otherwise. & $15 \%$ & $21 \%$ & $7 \%$ & $4 \%$ & $3 \%$ \\
\hline TOTAL & & $100 \%$ & $100 \%$ & $100 \%$ & $100 \%$ & $100 \%$ \\
\hline \multicolumn{7}{|l|}{ Household Characteristics } \\
\hline "SWD" Mother & Dummy variable, 1 if household is headed by a single, widowed or divorced mother, 0 otherwise. & $20 \%$ & $19 \%$ & $18 \%$ & $19 \%$ & $24 \%$ \\
\hline Disabled Person & Dummy variable, 1 if there is at least one disabled household member, 0 otherwise. & $16 \%$ & $12 \%$ & $18 \%$ & $23 \%$ & $24 \%$ \\
\hline Indigenous background & Dummy variable, 1 if there is at least one household member that speaks a native language, 0 otherwise. & $9 \%$ & $6 \%$ & $11 \%$ & $14 \%$ & $15 \%$ \\
\hline TOTAL & & $45 \%$ & $37 \%$ & $47 \%$ & $56 \%$ & $63 \%$ \\
\hline
\end{tabular}


Table 1 Variable names, definitions, and descriptive statistics related to food security levels (Continued)

\begin{tabular}{|c|c|c|c|c|c|c|}
\hline Lower Income & Dummy variable, 1 if household income is below the food poverty line, 0 otherwise. & $16 \%$ & $9 \%$ & $22 \%$ & $30 \%$ & $34 \%$ \\
\hline Low Income & $\begin{array}{l}\text { Dummy variable, } 1 \text { if household income is above the food poverty line but below the assets } \\
\text { poverty line, } 0 \text { otherwise. }\end{array}$ & $27 \%$ & $22 \%$ & $35 \%$ & $36 \%$ & $34 \%$ \\
\hline Middle Income & $\begin{array}{l}\text { Dummy variable, } 1 \text { if household income is higher than the assets poverty line but lower than } \\
\text { twice the assets poverty line, } 0 \text { otherwise. }\end{array}$ & $31 \%$ & $32 \%$ & $31 \%$ & $27 \%$ & $23 \%$ \\
\hline Higher Income & Dummy variable, 1 if household income is higher than twice the assets poverty line, 0 otherwise. & $26 \%$ & $37 \%$ & $12 \%$ & $7 \%$ & $9 \%$ \\
\hline TOTAL & & $100 \%$ & $100 \%$ & $100 \%$ & $100 \%$ & $100 \%$ \\
\hline Social Program Participant & $\begin{array}{l}\text { Dummy variable, } 1 \text { if household receives benefits from a conditional cash transfer program } \\
\text { (Oportunidades or Apoyo Alimentario), } 0 \text { otherwise. }\end{array}$ & $18 \%$ & $11 \%$ & $25 \%$ & $30 \%$ & $30 \%$ \\
\hline Agricultural Household & Dummy variable, 1 if at least $1 / 4$ of household's income comes from agricultural activities, 0 otherwise. & $2 \%$ & $2 \%$ & $3 \%$ & $2 \%$ & $2 \%$ \\
\hline Unitary Household & $\begin{array}{l}\text { Dummy variable, } 1 \text { if (household head }=1 \text { and spouse }=0 \text { and children }=0 \text { and relatives }=0 \text { and } \\
\text { no relatives }=0 \text { ), } 0 \text { otherwise. }\end{array}$ & $10 \%$ & $11 \%$ & $6 \%$ & $6 \%$ & $13 \%$ \\
\hline Traditional Household & $\begin{array}{l}\text { Dummy variable, } 1 \text { if (household head }=1 \text { and (spouse }>0 \text { or children }>0 \text { ) and relatives }=0 \text { and } \\
\text { no relatives }=0 \text { ), } 0 \text { otherwise. }\end{array}$ & $66 \%$ & $67 \%$ & $67 \%$ & $66 \%$ & $61 \%$ \\
\hline Extended Household & $\begin{array}{l}\text { Dummy variable, } 1 \text { if (household head }=1 \text { and (spouse }>0 \text { or children }>0 \text { or relatives }>0 \text { ) and no } \\
\text { relatives }=0 \text { ), } 0 \text { otherwise. }\end{array}$ & $23 \%$ & $21 \%$ & $26 \%$ & $28 \%$ & $25 \%$ \\
\hline Composite Household & $\begin{array}{l}\text { Dummy variable, } 1 \text { if (household head }=1 \text { and (spouse }>0 \text { or children }>0 \text { or relatives }>0 \text { ) and no } \\
\text { relatives }>0 \text { ), } 0 \text { otherwise. }\end{array}$ & $1 \%$ & $1 \%$ & $1 \%$ & $1 \%$ & $1 \%$ \\
\hline Co-resident Household & $\begin{array}{l}\text { Dummy variable, } 1 \text { if (household head }=1 \text { and spouse }=0 \text { and children }=0 \text { and relatives }=0 \text { and } \\
\text { no relatives }>0 \text { ), } 0 \text { otherwise. }\end{array}$ & $0 \%$ & $1 \%$ & $0 \%$ & $0 \%$ & $0 \%$ \\
\hline TOTAL & & $100 \%$ & $100 \%$ & $100 \%$ & $100 \%$ & $100 \%$ \\
\hline Kids 0 & Dummy variable, 1 if there are no kids ( $<18$ y old), 0 otherwise. & $36 \%$ & $42 \%$ & $29 \%$ & $20 \%$ & $35 \%$ \\
\hline Kids 1 & Dummy variable, 1 if there is $1 \mathrm{kid}, 0$ otherwise. & $22 \%$ & $22 \%$ & $24 \%$ & $22 \%$ & $15 \%$ \\
\hline Kids 2 & Dummy variable, 1 if there are 2 children, 0 otherwise. & $22 \%$ & $21 \%$ & $24 \%$ & $27 \%$ & $19 \%$ \\
\hline Kids 3 & Dummy variable, 1 if there are 3 children, 0 otherwise. & $13 \%$ & $10 \%$ & $15 \%$ & $19 \%$ & $16 \%$ \\
\hline Kids 4 & Dummy variable, 1 if there are 4 children, 0 otherwise. & $4 \%$ & $3 \%$ & $5 \%$ & $7 \%$ & $8 \%$ \\
\hline Kids $>4$ & Dummy variable, 1 if there are more than 4 children, 0 otherwise. & $3 \%$ & $1 \%$ & $3 \%$ & $5 \%$ & $7 \%$ \\
\hline TOTAL & & $100 \%$ & $100 \%$ & $100 \%$ & $100 \%$ & $100 \%$ \\
\hline
\end{tabular}


Table 1 Variable names, definitions, and descriptive statistics related to food security levels (Continued)

\begin{tabular}{|c|c|c|c|c|c|c|}
\hline \multicolumn{7}{|c|}{ Community and Regional Variables } \\
\hline Large City & Dummy variable, 1 if the household is located in a city with more than 100,000 inhabitants, 0 otherwise. & $51 \%$ & $58 \%$ & $40 \%$ & $40 \%$ & $40 \%$ \\
\hline Medium City & $\begin{array}{l}\text { Dummy variable, } 1 \text { if the household is located in a city with population between } 15,000 \text { and } \\
99,999 \text { inhabitants, } 0 \text { otherwise. }\end{array}$ & $15 \%$ & $15 \%$ & $15 \%$ & $14 \%$ & $14 \%$ \\
\hline Small City & $\begin{array}{l}\text { Dummy variable, } 1 \text { if the household is located in a city with population between 2,500 and 14,999 } \\
\text { inhabitants, } 0 \text { otherwise. }\end{array}$ & $14 \%$ & $12 \%$ & $16 \%$ & $16 \%$ & $16 \%$ \\
\hline Rural Community & Dummy variable, 1 if the household is located in a city with less than 2,500 inhabitants, 0 otherwise. & $21 \%$ & $16 \%$ & $28 \%$ & $29 \%$ & $31 \%$ \\
\hline TOTAL & & $100 \%$ & $100 \%$ & $100 \%$ & $100 \%$ & $100 \%$ \\
\hline Region 1 & $\begin{array}{l}\text { Dummy variable, } 1 \text { if the household is in Socioeconomic Region } 1 \text { (Chiapas, Guerrero, and } \\
\text { Oaxaca), } 0 \text { otherwise. }\end{array}$ & $10 \%$ & $7 \%$ & $14 \%$ & $14 \%$ & $12 \%$ \\
\hline Region 2 & $\begin{array}{l}\text { Dummy variable, } 1 \text { if the household is in Socioeconomic Region } 2 \text { (Campeche, Hidalgo, Puebla, } \\
\text { San Luis Potosi, Tabasco, and Veracruz), } 0 \text { otherwise. }\end{array}$ & $19 \%$ & $17 \%$ & $22 \%$ & $22 \%$ & $23 \%$ \\
\hline Region 3 & $\begin{array}{l}\text { Dummy variable, } 1 \text { if the household is in Socioeconomic Region } 3 \text { (Durango, Guanajuato, } \\
\text { Michoacán, Tlaxcala, and Zacatecas), } 0 \text { otherwise. }\end{array}$ & $12 \%$ & $12 \%$ & $12 \%$ & $12 \%$ & $12 \%$ \\
\hline Region 4 & $\begin{array}{l}\text { Dummy variable, } 1 \text { if the household is in Socioeconomic Region } 4 \text { (Colima, Estado de Mexico, } \\
\text { Morelos, Nayarit, Queretaro, Quintana Roo, Sinaloa, and Yucatan), } 0 \text { otherwise. }\end{array}$ & $23 \%$ & $22 \%$ & $25 \%$ & $27 \%$ & $24 \%$ \\
\hline Region 5 & $\begin{array}{l}\text { Dummy variable, } 1 \text { if the household is in Socioeconomic Region } 5 \\
\text { (Baja California, Baja California Sur, Chihuahua, Sonora, and Tamaulipas), } 0 \text { otherwise. }\end{array}$ & $13 \%$ & $15 \%$ & $9 \%$ & $8 \%$ & $11 \%$ \\
\hline Region 6 & $\begin{array}{l}\text { Dummy variable, } 1 \text { if the household is in Socioeconomic Region } 6 \text { (Aguascalientes, Coahuila, } \\
\text { Jalisco, and Nuevo Leon), } 0 \text { otherwise. }\end{array}$ & $14 \%$ & $15 \%$ & $13 \%$ & $11 \%$ & $12 \%$ \\
\hline Region 7 & Dummy variable, 1 if the household is in Socioeconomic Region 7 (Mexico City), 0 otherwise. & $9 \%$ & $11 \%$ & $6 \%$ & $5 \%$ & $6 \%$ \\
\hline TOTAL & & $100 \%$ & $100 \%$ & $100 \%$ & $100 \%$ & $100 \%$ \\
\hline
\end{tabular}

Weighted summary statistics reported. Sample size: 61,467 households 
Table 2 Regression coefficients and marginal effects (Robust estimation)

\begin{tabular}{|c|c|c|c|c|c|}
\hline \multirow[b]{3}{*}{ Variable } & \multirow[b]{3}{*}{ Coefficients } & \multicolumn{4}{|c|}{ Marginal effects } \\
\hline & & \multirow[b]{2}{*}{ Food security } & \multicolumn{3}{|c|}{ Food insecurity } \\
\hline & & & Very low & Moderate & Severe \\
\hline Age $31-45$ & -0.056 & 0.019 & -0.004 & -0.006 & -0.009 \\
\hline Age $46-60$ & -0.076 & 0.025 & -0.006 & -0.008 & -0.012 \\
\hline Age $>=61$ & $-0.324^{* * *}$ & $0.108^{* * *}$ & $-0.024^{* * *}$ & $-0.033^{* * *}$ & $-0.051^{* * *}$ \\
\hline Male & $-0.074^{* *}$ & $0.025^{* *}$ & $-0.006^{* *}$ & $-0.007^{* *}$ & $-0.011^{* *}$ \\
\hline Elementary & $-0.246^{* * *}$ & $0.082^{* * *}$ & $-0.019^{* * *}$ & $-0.025^{* * *}$ & $-0.038^{* * *}$ \\
\hline Secondary & $-0.379^{* * *}$ & $0.126^{* * *}$ & $-0.029^{* * *}$ & $-0.038^{* * *}$ & $-0.059^{* * *}$ \\
\hline High School & $-0.608^{* * *}$ & $0.202^{* * *}$ & $-0.046^{* * *}$ & $-0.062^{* * *}$ & $-0.095^{* * *}$ \\
\hline College & $-0.853^{* * *}$ & $0.284^{* * *}$ & $-0.064^{* * *}$ & $-0.087^{* * *}$ & $-0.133^{* * *}$ \\
\hline "SWD" Mother & $0.065^{*}$ & $-0.022^{*}$ & $0.005^{*}$ & $0.007^{*}$ & $0.010^{*}$ \\
\hline Disable Person & $0.320^{* * *}$ & $-0.107^{* * *}$ & $0.024^{* * *}$ & $0.033^{* * *}$ & $0.050^{* * *}$ \\
\hline Native Language & $0.110^{* * *}$ & $-0.037^{* * *}$ & $0.008^{* * *}$ & $0.011^{* * *}$ & $0.017^{* * *}$ \\
\hline Low Income & $-0.255^{* * *}$ & $0.085^{* * *}$ & $-0.019^{* * *}$ & $-0.026^{* * *}$ & $-0.04^{* * *}$ \\
\hline Middle Income & $-0.536^{* * *}$ & $0.178^{* * *}$ & $-0.040^{* * *}$ & $-0.054^{* * *}$ & $-0.083^{* * *}$ \\
\hline Higher Income & $-1.062^{* * *}$ & $0.354^{* * *}$ & $-0.080^{* * *}$ & $-0.108^{* * *}$ & $-0.166^{* * *}$ \\
\hline Agricultural HH & $-0.17^{* * *}$ & $0.057^{* * *}$ & $-0.013^{* * *}$ & $-0.017^{* * *}$ & $-0.027^{* * *}$ \\
\hline Traditional HH & $-0.283^{* * *}$ & $0.094^{* * *}$ & $-0.021^{* * *}$ & $-0.029^{* * *}$ & $-0.044^{* * *}$ \\
\hline Extended $\mathrm{HH}$ & $-0.318^{* * *}$ & $0.106^{* * *}$ & $-0.024^{* * *}$ & $-0.032^{* * *}$ & $-0.050^{* * *}$ \\
\hline Composite HH & -0.046 & 0.015 & -0.003 & -0.005 & -0.007 \\
\hline Co-resident HH & -0.207 & 0.069 & -0.016 & -0.021 & -0.032 \\
\hline Kids 1 & 0.041 & -0.014 & 0.003 & 0.004 & 0.006 \\
\hline Kids 2 & $0.072^{* *}$ & $-0.024^{* *}$ & $0.005^{* *}$ & $0.007^{* *}$ & $0.011^{* *}$ \\
\hline Kids 3 & $0.146^{* * *}$ & $-0.049^{* * *}$ & $0.011^{* * *}$ & $0.015^{* * *}$ & $0.023^{* * *}$ \\
\hline Kids 4 & $0.227^{* * *}$ & $-0.076^{* * *}$ & $0.017^{* * *}$ & $0.023^{* * *}$ & $0.035^{* * *}$ \\
\hline Kids $>4$ & $0.344^{* * *}$ & $-0.114^{* * *}$ & $0.026^{* * *}$ & $0.035^{* * *}$ & $0.054^{* * *}$ \\
\hline Large City & $-0.075^{* * *}$ & $0.025^{* * *}$ & $-0.006^{* * *}$ & $-0.008^{* * *}$ & $-0.012^{* * *}$ \\
\hline Medium City & $-0.125^{* * *}$ & $0.042^{* * *}$ & $-0.009^{* * *}$ & $-0.013^{* * *}$ & $-0.019 * * *$ \\
\hline Small City & $-0.084^{* * *}$ & $0.028^{* * *}$ & $-0.006^{* * *}$ & $-0.008^{* * *}$ & $-0.013^{* * *}$ \\
\hline Region 1 & $0.126^{* * *}$ & $-0.042^{* * *}$ & $0.009^{* * *}$ & $0.013^{* * *}$ & $0.020^{* * *}$ \\
\hline Region 2 & $0.133^{* * *}$ & $-0.044^{* * *}$ & $0.010^{* * *}$ & $0.013^{* * *}$ & $0.021^{* * *}$ \\
\hline Region 3 & -0.004 & 0.001 & -0.0003 & -0.0004 & -0.001 \\
\hline Region 4 & $0.216^{* * *}$ & $-0.072^{* * *}$ & $0.016^{* * *}$ & $0.022^{* * *}$ & $0.034^{* * *}$ \\
\hline Region 5 & -0.060 & 0.020 & -0.005 & -0.006 & -0.009 \\
\hline Region 6 & $0.076^{* *}$ & $-0.025^{* *}$ & $0.006^{* *}$ & $0.008^{* *}$ & $0.012^{* *}$ \\
\hline
\end{tabular}

Sample size: 61,467 households. $\mathrm{HH}=$ Household. "SDW" = Single, Divorced or Widowed

${ }^{*} p<.1,{ }^{* *} p<.05,{ }^{* * *} p<.01$

that, even though they are correlated, food security and poverty are two different dimensions of welfare.

Coefficient estimates and $p$-values from the ordered probit model, as well as marginal effects for the four levels of food security are reported in Table 2. Given the complex design of the sample, weighted data should be used for estimation (Instituto Nacional de Estadística y Geografía. México INEGI (2011). Discussion focuses on marginal effects (post-estimation) since coefficients from ordered probit do not have a direct interpretation. 
The marginal effects for variable Age $>=61$ indicate that these households are 10.8 percentage points more likely to be food secure than those with household head younger than 30 years old, which is the omitted category. This result may suggest that, on average, as age of household head increases she/he gets more experience in managing the resources in the household and, possible, more experience at work may represent higher disposable income, reducing the probability of the household to be food insecure. Moreover, the probability of having children at this age is expected to be very low, which implies less family members.

Turning to gender of household head, once all other covariates are controlled for, a male-headed household is 2.5 percentage points more likely to be food secure than a female-headed household.

In terms of education level of the household head, all variables related to a level of formal education have positive marginal effects for the food security category compared to the omitted category No formal education. That is, a household headed by a person that has elementary school as maximum level of formal education is 8.2 percentage points more likely to be food secure than a household headed by a person with no formal education. This marginal effect is 12.6, 20.2, and 28.4 percentage points for the variables Secondary, High School and College, respectively. This result suggests that education is an important variable that affects the probability of a favorable food security status. On the other hand, negative marginal effects were obtained for each of the three categories of food insecurity in terms of education levels. In particular, a household headed by a person with high school education is 9.5 percentage points less likely to be severe food insecure than a household headed by a person with no formal education.

A household with a family member that is disabled is 10.7 percentage points less likely to be food secure, compared to a household that does not share this characteristic. Likewise, the probability of being food secure for a household where native language is 3.7 percentage points lower than that for a non-indigenous household. This finding is consistent with conclusions in previous studies such as Oseguera-Parra (2010), who found that urban and mestizo -non-indigenous- women perceive less food insecurity compared to rural and indigenous women.

Regarding variables related to income the omitted variable was Lower income, thus the marginal effects of Low income, Middle income, and High income are compared to that category. It turns out that all marginal effects are positive for food security and negative for each of the categories of food insecurity. This implies that, as MelgarQuiñonez et al. (2006) also found, income is an important determinant of food security. As a particular example, Middle income households are 17.8 percentage points more likely to be food secure than those household in the reference category (Lower income), and they are also 5.4 percentage points less likely to be moderate food insecure. Similarly, Low income households are 4.0 percentage points less likely to be under severe food insecurity than those households in the reference category.

An Agricultural household is 5.7 percentage points more likely to be food secure than a type of household that is not considered under this definition. Recall that, for modelling purposes, it is considered an agricultural household if the income from agricultural activities is at least $1 / 4$ of total household income. Moreover, an agricultural household is 2.7 percentage points less likely to suffer severe food insecurity. This result makes 
intuitive sense, since a household that receives income from agricultural activities may be more likely to also produce food for own consumption.

Marginal effects for household types are positive in the food security column. That is, Traditional households and Extended households are more likely to be food secure than Unitary households. This could be because in a non-unitary household there may be more persons receiving income and they can achieve some economies of scale in terms of food consumption. Also, in a non-unitary household there may be a person in charge of preparing food, which may represent a way to take better advantage of the food resources at hand. Multidimensional poverty.

Variables related to number of children in the household have negative marginal effects as for food security is concerned. That is, when compared to the omitted category, No kids, households with two kids, three kids, four kids and more than four kids are 2.4, 4.9, 7.6, and 11.4 percentage points, respectively, less likely to be food secure. As expected the marginal effects are positive for each of the food insecurity categories, meaning that the probability of being food insecure is higher for households with kids. These probabilities increase monotonically with the number of kids in the household (see Table 2).

Households that live in rural communities appear to be more vulnerable than those living in larger communities/cities. Namely, controlling for variables related to household head characteristics and household composition, households that live in large cities are 2.5 percentage points more likely to be food secure than those living in rural communities (omitted category). This marginal effect is even greater, 4.2 and 2.8 percentage points, for households living in medium and small cities, respectively. This result may be related to the level of isolation, since there are rural communities that do suffer from lack of access to development opportunities (jobs, education, health care, etc.). Since poverty and food insecurity is a relevant problem in rural communities, a more detailed analysis is provided below. That is, determinants of food insecurity are analyzed in below for this particular population group.

Finally, in terms of geographic regions, in average households in Region3 and Region 5 are, respectively, 0.1 and 2.0 percentage points more likely to be food secure than those in Region7. Conversely, households in Region1, Region2, Region4 and Region6 are more likely to be food insecure than the households in Region7, which is Mexico City.

Focusing on an important vulnerable population subgroup, which consists of rural households with incomes below the food poverty line (Lower income), the regression analysis is performed using a sample of 4343 households that meet these two aspects (rural and Lower income).

Level of formal education of household head is an important determinant of food security in rural areas. As shown in Table 3, the marginal effects of all levels of education are positive and highly significant for food security and for very low food insecurity, levels that represent the two best categories in the food security scale. Education may be important to food security not only because it is usually correlated with income, but also because it may have a positive impact on how the resources in the household are managed. On this matter, Gundersen and Garasky (2012) found that households with greater financial management abilities are less likely to be food insecure. This finding holds even for households with incomes $<200 \%$ of the poverty line in the United 
Table 3 Regression coefficients and marginal effects for lower income households in rural communities

\begin{tabular}{|c|c|c|c|c|c|}
\hline \multirow[b]{3}{*}{ Variable } & \multirow[b]{3}{*}{ Coefficients } & \multicolumn{4}{|l|}{ Marginal effects } \\
\hline & & \multirow[b]{2}{*}{ Food security } & \multicolumn{3}{|c|}{ Food insecurity } \\
\hline & & & Very low & Moderate & Severe \\
\hline Age 31-45 & -0.038 & 0.013 & 0.002 & -0.004 & -0.011 \\
\hline Age $46-60$ & 0.108 & -0.036 & -0.005 & 0.011 & 0.030 \\
\hline Age $>=61$ & 0.075 & -0.025 & -0.003 & 0.008 & 0.021 \\
\hline Male & -0.044 & 0.015 & 0.002 & -0.004 & -0.012 \\
\hline Elementary & $-0.300^{* * *}$ & $0.101^{* * *}$ & $0.013^{* * *}$ & $-0.030^{* * *}$ & $-0.085^{* * *}$ \\
\hline Secondary & $-0.347^{* * *}$ & $0.117^{* * *}$ & $0.015^{* * *}$ & $-0.035^{* * *}$ & $-0.098^{* * *}$ \\
\hline High School & $-0.666^{* * *}$ & $0.225^{* * *}$ & $0.029^{* * *}$ & $-0.066^{* * *}$ & $-0.188^{* * *}$ \\
\hline College & $-0.794^{*}$ & $0.268^{*}$ & $0.035^{*}$ & $-0.079^{*}$ & $-0.224^{*}$ \\
\hline Disable Person & $0.262^{* * *}$ & $-0.089^{* * *}$ & $-0.011^{* * *}$ & $0.026^{* * *}$ & $0.074^{* * *}$ \\
\hline Native Language & $0.166^{* * *}$ & $-0.056^{* * *}$ & $-0.007^{* * *}$ & $0.017^{* * *}$ & $0.047^{* * *}$ \\
\hline Social PP & -0.037 & 0.013 & 0.002 & -0.004 & -0.011 \\
\hline Agricultural HH & $-0.246^{* * *}$ & $0.083^{* * *}$ & $0.011^{* * *}$ & $-0.025^{* * *}$ & $-0.069 * * *$ \\
\hline Traditional HH & 0.199 & -0.067 & -0.009 & 0.020 & 0.056 \\
\hline Extended $\mathrm{HH}$ & -0.015 & 0.005 & 0.001 & -0.001 & -0.004 \\
\hline Composite $\mathrm{HH}$ & 0.400 & -0.135 & -0.017 & 0.040 & 0.113 \\
\hline Co-resident HH & $-1.032^{*}$ & $0.349^{*}$ & $0.045^{*}$ & $-0.103^{*}$ & $-0.291^{*}$ \\
\hline Kids 1 & $0.17^{* *}$ & $-0.058^{* *}$ & $-0.007^{* *}$ & $0.017^{* *}$ & $0.048^{* *}$ \\
\hline Kids 2 & $0.256^{* * *}$ & $-0.086^{* * *}$ & $-0.011^{* * *}$ & $0.026^{* * *}$ & $0.072^{* * *}$ \\
\hline Kids 3 & $0.257^{* * *}$ & $-0.087^{* * *}$ & $-0.011^{* * *}$ & $0.026^{* * *}$ & $0.073^{* * *}$ \\
\hline Kids 4 & $0.361^{* * *}$ & $-0.122^{* * *}$ & $-0.016^{* * *}$ & $0.036^{* * *}$ & $0.102^{* * *}$ \\
\hline Kids $>4$ & $0.541^{* * *}$ & $-0.183^{* * *}$ & $-0.024^{* * *}$ & $0.054^{* * *}$ & $0.153^{* * *}$ \\
\hline
\end{tabular}

Sample size: 4,343 households. $\mathrm{HH}=$ Household. Social $\mathrm{PP}=$ Social Program participation ${ }^{*} p<.1,{ }^{* *} p<.05,{ }^{* * *} p<.01$

States. These findings suggest that improving households' financial management skills has the potential to reduce food insecurity. It would be worth to explore if the same outcome holds for Mexican households and if that is the case, implementing training programs would help families to achieve food security.

Households that have disabled persons have increased probability of being moderate food insecure (2.6 percentage points) and severe food insecure (7.4 percentage points) compared to households in the alternative category. This is not a surprising result since taking care of a disabled person increases household expenses.

Native language is a variable that have negative marginal effects for food security ( -5.6 percentage points) and for very low food insecurity ( -0.7 percentage points). This means that the probability of a household, where at least one member speaks a native language, to be food secure is significantly lower compared to households that do not share the native language characteristic. It is worth noticing that even in the rurallower income subpopulation group the households with strong indigenous background are more likely (vulnerable) to be food insecure.

The marginal effects of participating in a social program, households that receive income from one of two government programs, Oportunidades or Apoyo Alimentario, are not statistically significant. This variable is only included in the estimation for the rural-lower income subpopulation group since the objective of the program is to reach 
households that live under poverty conditions. An alternative model specification (not reported) without including the variable for social program participation was estimated, finding that the estimates and marginal effects of the rest of the variables are practically unaffected when dropping such variable that could be considered as endogenous.

Estimation of a formal treatment effect of social program participation on food security is out of the scope of this research and it is left as an opportunity for future work. However, there is evidence in the literature that social program participation helps households to achieve better food security status. In particular, Ruiz-Arranz et al. (2002) analyze the impact on food security of two conditional cash transfer programs, Oportunidades (previously known as Progresa) and Procampo. Whereas Oportunidades is a transfer program aimed to help households through food consumption and the development of human capital, Procampo is an agricultural production program. The authors found that both programs boost total food consumption, and caloric intake in similar proportions. Moreover, both programs increase food diversity. However, households that were Procampo recipients that also receive Oportunidades, were more likely to have a more varied diet than households that receive benefits from Procampo only. The authors conclude that access to information on nutrition and health that accompanies Oportunidades has a positive effect on food diversity. That is, education and training provided to women seem to affect positively the way resources in the household are spent. Nevertheless, Torres Salcido (2010) suggests that certain vulnerable population has not yet received benefits from social programs in Mexico. Among the reasons for this exclusion, the author cites adverse ethnic characteristics, isolation of rural communities and lack of information.

Back to the description of results, agricultural households have increased probabilities to have a positive food security status. That is, an agricultural household in rural areas is 8.3 percentage points more likely to be food secure than a non-agricultural household. The definition of agricultural household is the same as in previous sections. Most agricultural households are eligible to receive benefits from Procampo and arguably are more likely to be better off than other households. Sadoulet, de Janvry, and Davis (2001) analyzed Procampo program in Mexico, finding that cash transfer programs can create multiplier effects, particularly when household recipients invest the money they receive to generate further incomes. The authors also find that these multipliers are higher for households with medium and large farms, low numbers of adults in the household, and households with nonindigenous backgrounds. Furthermore, they point out that opportunities are enhanced when recipient households have also access to technical assistance.

As for the number of children in the household, the marginal effects on food security of having one, two, three, four and more than four kids are $-5.8,-8.6,-8.7,-12.2$ and -18.3 percentage points, respectively. That is, households with kids are less likely to be food secure than households without children. Unsurprisingly, the probability of a household to have food security decreases as the number of kids in the household increase.

Common factors from the discussion above include: 1) education is an important determinant of food security, even in lower income households; 2) population with strong indigenous background, usually living in isolated communities, seem to be a vulnerable population segment in terms of food insecurity. Our hypothesis was that the more 
educated the head of household, the less likely they will suffer food insecurity. This is found to be true, and this was also found in Magaña-Lemus and J. Lara-Álvarez (2015). Therefore, we would expect that as the average education of head of household increases, food insecurity will decrease. More educated head households have the opportunity to take more informed decisions about its consumption and the importance of a healthy diet. Furthermore, those households are potentially more able to access and make better use of social programs to improve their nutrition.

\section{Conclusions}

The increase of food insecurity in Mexico has obvious policy implications and relevance. In this study we investigate how demographic variables are related to food security and to different degrees of food insecurity using a nationally representative data and a newly developed food security scale. The estimation was conducted using an ordered probit model for the total population first, and then for a subgroup of rural lower income households. We found that households with younger, less-educated household heads were more likely to suffer food insecurity. Other groups that were found to be vulnerable in terms of food insecurity include households headed by a single, widow or divorced mother, households with disabled family members, households with strong indigenous background, rural households, low income families, non-agricultural households and households with children.

Since households in rural areas and with income below the food poverty line were found to be a vulnerable group, estimation for this subgroup was conducted separately. Vulnerable groups in rural, lower income subgroup still include households with strong indigenous background (Native language), households with disabled family members and households with a large number of children. It seems that is necessary not only to implement policies that will bring the benefits of cash transfer social programs to the residents of isolated rural communities but also to implement/strengthen complementary public policies to support sustainable local food production and rural development.

We found that the level of education is yet an important determinant of food security even among lower income families in rural areas. Education may be important to food security not only because it is usually correlated with income, but also because it may have a positive impact on how the resources in the household are managed. Gundersen and Garasky (2012) suggest that improving households' financial management skills has the potential to reduce food insecurity in the United States. If the same outcome will hold for Mexican households, implementing training programs would help families to improve food security.

Within the rural and lower income subpopulation, a variable related to favorable food security status is whether or not the household is an agricultural household. Sadoulet, de Janvry, and Davis (2001) analyzed the Procampo program in Mexico, finding that cash transfer programs can create multiplier effects. They also point out that opportunities are enhanced when recipient households have also access to technical assistance. Hence, education (technical training) seems to play an important role to achieve food security in agricultural households as well.

As for opportunities for future research, one way to expand the present work is to evaluate social program participation using food security as dependent variable. This 
could be done by using formal treatment effect methods and correcting for endogenous program participation. In fact, besides further measurements in the MCS of ENIGH, INEGI is planning to implement the EMSA on a quarter basis on the ENGASTO (Encuesta Nacional de Gastos de los Hogares), then it would be interesting to analyze whether food security has a seasonal component. Future research can also include the estimation of household food security determinants for particular geographic regions or demographic subgroups of interest, which may have the potential to identify relevant variables to help the design of development programs.

\section{Endnotes}

${ }^{1}$ Since 2008, EMSA takes 12 out of 16 questions from ELCSA. 4 questions had implementation problems in the MCS from 2008.

${ }^{2}$ It is important to notice that CONEVAL includes the degree of food security in its multidimensional measurement of poverty.

${ }^{3}$ There is a concern in the literature about this assumption. In specific, Davidson and Mackinnon (1984) seminal paper showed that the parameters estimates will be inconsistent if we ignored the heteroskedasctiticy and simply maximized the log-likelihood. Some authors like Johnson (1996), Glewwe (1997) and Weiss (1997) have also argued this and proposed a test for normality in the ordered probit. However, a code for this test, unfortunately, has not been implemented yet in Stata. Therefore, the authors used the routine by David Giles in Eviews (available here: http://web.uvic.ca/ dgiles/downloads/ binary_choice/index.html). The test is a Langrage Multiplier (LM) where the null hypothesis is that the errors are distributed normal. The null was not rejected. Another less formal option to test this assumption is to compare the results of the robust and usual standard errors. This was implemented and the results were also satisfactory.

${ }^{4}$ It is worth noticing that there were small numerical difference between the regular standard error, which confirm our hypothesis of non-heterocedasticity.

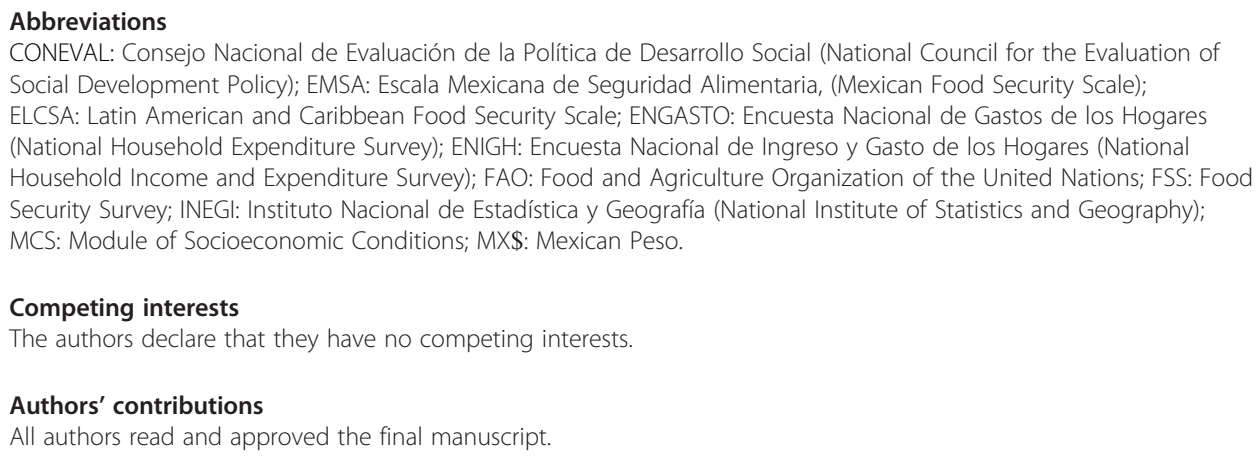


Bickel G, Nord M, Price C, Hamilton W, Cook J (2000) "Guide to Measuring Household Food Security." U.S. Department of Agriculture, Food and Nutrition Service, Alexandria, VA. Available at: http://www.fns.usda.gov/sites/default/files/ FSGuide.pdf (accessed November 2012)

Carmichael SL, Yang W, Herring A, Abrams B, Shaw GM (2007) Maternal Food Insecurity is Associated with Increased Risk of Certain Birth Defects. J Nutr 137(9):2087-2092

Carrasco B, Peinador R, Aparicio R (2010) "La Escala Mexicana de Seguridad Alimentaria en la ENIGH: Evidencias de la Relación entre la Inseguridad Alimentaria y la Calidad de la Dieta en Hogares Mexicanos." Presented at the X Reunión Nacional de Investigación Demográfica en México de la Sociedad Mexicana de Demografía, México, D.F., November 5th, 2010. Available at: http://www.somede.org/documentos/Xreunion/ponencias/N_20_1.pdf (accessed October 2012)

Consejo Nacional de Evaluación de la Política de Desarrollo Social (CONEVAL) (2010) "Dimensiones de la Seguridad Alimentaria: Evaluación Estratégica de Nutrición y Abasto." Available at: http://www.coneval.gob.mx/mw/resource/coneval/info_public/ PDF_PUBLICACIONES/Dimensiones_seguridad_alimentaria_FINAL_web.pdf (Accessed February 2013)

Consejo Nacional de Evaluación de la Política de Desarrollo Social (CONEVAL) (2011a) "Anexo Estadístico del Informe de Medición de Pobreza 2010." Available at: http://www.coneval.gob.mx/Medicion/MP/Paginas/Anexoestad\%C3\%ADsticomunicipal-2010.aspx (accessed September 2012)

Consejo Nacional de Evaluación de la Política de Desarrollo Social (CONEVAL) (2011b) "Nota Técnica para la Medición de la Pobreza, 2008-2010." Available at: http://www.coneval.gob.mx/Medicion/MP/Paginas/Resultados_nal_20082012_sin_combustible.aspx (accessed October 2012)

Cook JT, Frank DA, Levenson SM, Neault NB, Heeren TC, Black MM, Berkowitz C, Casey PH, Meyers AF, Cutts DB, Chilton M (2006) Child Food Insecurity Increases Risks Posed by Household Food Insecurity to Young Children's Health. J Nutr 136(4):1073-1076

Davidson R, MacKinnon JG (1984) Convenient specification tests for logit and probit models. J Econom 25(3):241-262

FAO (1996) "Declaration on world food security." World Food Summit, FAO, 1996

FAO (2009) "Declaration of the World Summit on Food Security." World Summit on Food Security. November, 2009

FAO (2012) Escala Latinoamericana y Caribeña de Seguridad Alimentaria (ELCSA). http://www.fao.org/3/a-i3065s.pdf. (accessed Feb 2015)

Glewwe P (1997) A test of the normality assumption in the ordered probit model. Econ Rev 16:1-19

González W, Jiménez A, Madrigal G, Muñoz LM, Frongillo EA (2008) Development and Validation of Measure of Household Food Insecurity in Urban Costa Rica Confirms Proposed Generic Questionnaire. J Nutr 138(3):587-592

Greene WH (2012) Econometric Analysis (7th edition). New York University, USA: Prentice Hall

Gulliford MC, Mahabir D, Rocke B (2004) Reliability and Validity of a Short Form Household Food Security Scale in a Caribbean community. BMC Public Health 4:22

Gundersen CG (2008) Measuring the Extent, Depth, and Severity of Food Insecurity: an Application to American Indians in the USA. J Popul Econ 21:191-215

Gundersen CG, Garasky SB (2012) Financial Management Skills Are Associated with Food Insecurity in a Sample of Households with Children in the United States. J Nutr 142(10):1865-1870

Gundersen CG, Kreider B, Pepper J (2011) The Economics of Food Insecurity in the United States. AEPP 33(3):281-303

Hager ER, Quigg AM, Black MM, Coleman SM, Heeren T, Rose-Jacobs R, Cook JT, Ettinger de Cuba SA, Casey PH, Chilton M, Cutts DB, Meyers AF, Frank DA (2010) Development and Validity of a 2-Item Screen to Identify Families at Risk for Food Insecurity. Pediatrics 126(1):e26-e32

Instituto Nacional de Estadística y Geografía. México (INEGI (2011) "Encuesta Nacional de Ingresos y Gastos de los Hogares (2010). Módulo de Condiciones Socioeconómicas: Encuesta Nacional de Ingresos y Gastos de los Hogares 2010: Descripción de la Base de Datos." Instituto Nacional de Estadística y Geografía, México

Instituto Nacional de Estadística y Geografía. México (INEGI). (2012) "Regiones Socioeconomicas de Mexico." Available at http://sc.inegi.org.mx/niveles/index.jsp (accessed November 2012)

Johnson PA (1996) A test of the normality assumption in the ordered probit model. Metron 54:213-221

Jyoti DF, Frongillo EA, Jones SJ (2005) Food Insecurity Affects School Children's Academic Performance, Weight Gain, and Social Skills. J Nutr 135(12):2831-2839

Long JS, Freese J (2006) Regression Models for Categorical Dependent Variables Using Stata, 2nd edn. Stata Press, College Station, TX

Magaña-Lemus D, Lara-Álvarez J (2015) "Food Security Measurement: An Empirical Approach", in Andrew Schmitz, P. Lynn Kennedy, Troy G. Schmitz (ed.) Food Security in an Uncertain World (Frontiers of Economics and Globalization, Volume 15) Bingley, UK: Emerald Group Publishing Limited; pp. 49-62. http://www.emeraldinsight. com/doi/abs/10.1108/S1574-871520150000015004

Melgar-Quiñonez HR, Zubieta AC, MkNelly B, Nteziyaremye A, Gerardo MFD, Dunford C (2006) Household Food Insecurity and Food Expenditure in Bolivia, Burkina Faso, and the Philippines. J Nutr 136(5):1431S-1437S

Melgar-Quiñonez H, Zubieta AC, Valdez E, Whitelaw B, Kaiser L (2005) Validación de un Instrumento para Vigilar la Inseguridad Alimentaria en la Sierra de Manantlán, Jalisco. Salud Publica Mex 47:413-422

Oseguera-Parra D (2010) Del Campo y la Ciudad: Percepción Social de la (In)seguridad Alimentaria. Estudios sobre las Culturas Contemporaneas 36(32):9-40

Pérez-Escamilla R, Correa-Segall A, Kurdian L, Archanjo M, Marín-León L, Panigassi G (2004) An Adapted Version of the U.S. Department of Agriculture Food Insecurity Module Is a Valid Tool for Assessing Household Food Insecurity in Campinas, Brazil. J Nutr 134:1923-1928

Pérez-Escamilla R, Paras P, Hromi-Fiedler A (2008) "Validity of the Latin American and Caribbean Household Food Security Scale (ELCSA) in Guanajuato, Mexico." The FASEB Journal 22:871.2

Ramsey R, Giskes K, Turrell G, Gallegos D (2011) Food Insecurity among Australian Children : Potential Determinants, Health and Developmental Consequences. J Child Health Care 15:401

Ruiz-Arranz M, Davis B, Stampini M, Winters P, Handa S (2002) "More Calories or more Diversity? An Econometric Evaluation of the Impact of the PROGRESA and PROCAMPO Transfer Programs on Food 
Security in Rural Mexico." ESA Working Paper No. 02-09. Available at: http://www.fao.org/docrep/007/ ae028e/ae028e00.htm (accessed March 2013)

Sadoulet E, de Janvry A, Davis B (2001) Cash Transfer Programs with Income Multipliers: Procampo in Mexico. World Dev 29(6):1043-1056

Torres Salcido G (2010) Intensidad de la Pobreza Alimentaria en las Zonas Rurales. Localización y Nuevas Perspectivas para el Desarrollo Rural. Revista Estudios Agrarios 44:47-61

Villagómez-Ornelas, Paloma, Hernández-López, Pedro, Carrasco-Enríquez, Brenda, Barrios-Sánchez, Karina, Pérez-Escamilla, Rafael, Melgar-Quiñónez, Hugo (2014) "Validez estadística de la Escala Mexicana de Seguridad Alimentaria y la Escala Latinoamericana y Caribeña de Seguridad Alimentaria". Salud Pública de México 56(Supl. 1):s5-s11

Weiss AA (1997) Specification tests in ordered logit and probit models. Econ Rev 16:361-391

Submit your manuscript to a SpringerOpen ${ }^{\circ}$ journal and benefit from:

- Convenient online submission

- Rigorous peer review

- Immediate publication on acceptance

- Open access: articles freely available online

- High visibility within the field

- Retaining the copyright to your article

Submit your next manuscript at $>$ springeropen.com 